mando. Na confluência dessas duas séries seria possível observarem-se as condiçốes e possibilidades de discursos profissionais específicos. Acima de tudo, o que Sandy e Holmwood estảo propondo é uma postura perante a vida. $O$ desencantamento weberiano deve ser o instrumento fundamental do cientista ao olhar a sociedade, a sua própria obra e, talvez, a sí mesmo.

Retomando a introdução desta resenha, Sandy continua sendo uma pessoa cativante, porém, ao propor uma critica ao "estabelecimento" sociologico, os autores sucumbem às duas falácias pois não vâo além da crítica.

A teoria da ação que emerge na leitura do livro revela-se no fazer sociologico que, ao descobrir, também transforma o mundo. Ao longo de capítulos onde são aprofundadas as contradiçoes entre racionalidade e açã̃o, ação e estrutura, poder e ordem normativa, estrutura e função, falsá consciência e alienação ontológica, os autores descobrem a perpetuação de falácias horizontais e verticais na obra de diversos cientistas sociais (Parsons, Giddens, Habermas), porém, não vão além da crítica, como eles próprios reconhece:

"Não temos metodologia para oferecer, nem rotinas para criativamente resolver problemas. A soluçno de problemas origina novos dados e novas relaçóes. Metodologias são resultados de práticas atuais e estão baseadas em esquemas que precisam ser transformados ao mesmo tempo que os problemas sia solucionados. Precisamos de nowos 'olhares' sociológicos $e$ nào de novas regras metodológicas. Tudo que podemos fazer é orientar os cientistas sociats para problemas que requerem a energia criativa deles..."

Em resumo, se Mozart ficasse somente criticando Salieri, possivelmente teríamos a mais lúcida e extensa crítica de Salieri, mas não teríamos Don Giovanni nem a Missa da Coroação.

O livro de Sandy e Holmwood ê de dificil leitura. porém, é um manual necessário para o aprendizado do trabalho intelectual ao se caminhar ao encontro da saborosa descoberta da indeterminaçăo da natureza e/ou da vida social, e não de encontro ao misterioso rigor do conhecimento competente sobre a natureza $\mathrm{e} /$ ou sobre as relações sociais

\section{BIBLIOGRAFIA}

BRAVERMAN, H. Labour and Monopoly Capitalism. New York, Monthly Review Press, 1974.

HOLLIS, M. "The Social Destruction of Reality". In: HOLLIS, M. \& LUKES, S. (orgs.) Rationality and Relatizism, Oxford, Basil Blackwell, 1982.

\title{
Reestruturação Urbana: Tendências e Desafios
}

\section{Licia Valladares e Edmond Pretecelle}

São Paulo, NOBELIUPERJ, 1990, 227 páginas.

Por Leonor M. Cámara, Socióloga, Mestre em Administração Pública e Planejamento, doutoranda em Administraçăo na EAESP/FGV, pesquisadora do CEDEC (Centro de Estudos e Cultura Contemporânea), professora da FEA/PUC/SP.

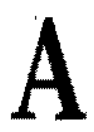
tualmente vivenciamos uma crise do processo de acumulação capitalista, haja vista a recessão nos Estados Unidos da América e o tatcherismo na Inglaterra, para citar apenas alguns exemplos. Simultaneamente, vivenciamos um processo de grandes transformaçōes urbanas que vêm ocorrendo em escala mundial, incluindo aí o redimensionamento do papel do urbano e da região na economia. $O$ desenvolvimento da tecnologia e as telecomunicações são indicadores desse processo e resultam na abertura das cidades aos mercados internacionais. A cidade e a regiáo não estão mais limitadas pelo espaço físico. Como resultado, podemos observaro surgimento de problemas urbanos em cidades localizadas em países desenvolvidos que até há pouco pensávamos serem específicos de cidades de países do Terceiro Mundo, como os problemas da habitação e degradaçăo urbana, por exemplo. A partir dessas constataçoes, os coordenadores da presente obra, Edmond Preteceille e Lícia Valladares, colocam as seguintes indagaçōes: Pode-se atribuir as transformaçōes 
urbanas exclusivamente às mudanças econômicas que vêm ocorrendo em escala massiva? Será que tais evoluçōes, que acompanham a globalização dos processos econômicos, obedecem a uma lógica única cuja compreensão seria a chave explicativa para as mudanças sociais em curso, dentre as quais as mudanças que vêm ocorrendo no urbano?

A presente obra reúne algumas comunicações apresentadas na conferência sobre Reestruturaçäo Urbana do grupo de Pesquisa de Desenvolvimento Regional e Urbano, da Associação Internacional de Sociologia (ISA), realizada na cidade do Rio de Janeiro em 1988. O critério de seleção dos trabalhos reunidos foi pautado naqueles que têm a análise centrada nos processos econômicos e de suas relaçóes com a reestruturação urbana. Esse critério, ao contrărio do que se pode pensar, não dá à obra um carăter economicista; muito pelo conträrio, privilegia análises que abordam criticamente os processos econômicos nas suas relaçōes com outras dimensóes dos processos sociais, sendo os próprios processos econômicos uma de suas dimensões.

Partindo das diversidades das vertentes de análises da pesquisa urbana, foi objeto da Conferencia: criar oportunidade de relacionamento entre diferentes abordagens de interpretação da questão regional e urbana; contrapor os resultados e as metodologias utilizadas nas pesquisas; e elaborar um balanço dos pressupostos teóricos atualmente em voga que "estäo levando a uma redrticulaçăo das diferentes abordagens e que propõem modos de compreensão capazes de dar conta da complexidade dos processos e das diversidades das práticas sociais"(pp. 8-9). A partir desses objetivos, os coordenadores da obra realizaram um corte seletivo dos trabalhos apresentados, selecionando as contribuições que apresentaram como ponto comum de análise a teoria da regulação.

Os objetivos da seleção dos trabalhos que compóem a obra são apresentar os conceitos-chave da Escola da Regulação e as questões levantadas quando da sua aplicação na análise comparativa de situações econồmicas e urbanas apresentadas pelos países capitalistas avançados e pela América Latina. A compreensào dos pressupostos teóricos da teoria da regulação é, portanto, esclarecedora do sentido da obra como um todo, isto é, é o que explica a articulação das contribuições que a compõem. Segundo os próprios organizadores, a teoria da regulação se opõe à visão quantitativa-contábil da acumulação capitalista. "Sua marca é dada pela dupla insistência sobre as caracteristicas do processo concreto de pro- duçäo e sobre as formas sociais globais hentro das quais opera a reprodução do modo de produção. Designando a crise como crise do regime fordista de acumulaçäo - crise do seu modelo de organizaçäo do trabalho, o taylorismo, e crise do seu modo de regulaçăo, o zelfare state -, a teoria da regulação reafirma a presença do politico no centro mesmo dos processos económicos: a organização do trabatho e o modo de regulação se estabelecem ou se desfazem nas Iutas, nos compromissos e nas relaços de forç". (p.9)

A estrutura da obra dá-se a partir de três grandes temas de análise. A primeira parte, "Pós-Fordismo: teoria e crítica do modelo da acumulação flexível", é composta pelos textos "Flexibilidade defensiva ou flexibilidade ofensiva: os desafios das novas tecnologias e da competição mundial", de Danielle Leborgne e Alain Lipietz; "Reestruturação industrial, pós-fordismo e novos espaços industriais: uma crítica", de Martin Boddy; "A teoria da crise e a reestruturação sócio-espacial dos Estados Unidos", de Mark Gottdiener; e "As divisões do trabalho no sistema manufatureiro global: tendências contrastantes na indústria automobilística mundial", de Richard Child Hill. Já a segunda parte, cujo tema é "Reestruturação urbano-industrial: impactos espaciais e regionais na América Latica", é composta pelos seguintes textos: "Tendências recentes e principais mudanças na estrutura espacial dos países latinoamericanos", de Samuel Jaramillo e Luis Maurício Cuervo; "A industrialização e a questão regional no Terceiro Mundo", de Michael Storper; "Classes, regimes fabris e mudança social no Nordeste Brasileiro", de Antônio Sérgio Alfredo Guimarães e Nadya A. Castro e "Regimes de acumulação, Estado e articulação de interesses na produção do espaço construído (Brasil, 19401980\%", de Marcus André B. C. de Melo. A terceira e última parte, denominada "Grandes metrópoles diante da crise", é composta pelos textos: "A metrópole: modernização, involução e segmentação", de Milton San-

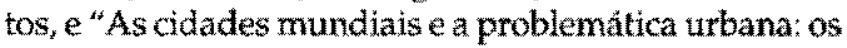
casos de Nova York e Tóquio", de William K. Tabb.

Por tratar-se de uma seleçăo de comunicaçôes, os textos que compöem a obra são curtos e bastante objetivos. $O$ modo como estão agrupados e articulados permite que o leitor tenha uma leitura bastante fluida, apesar de densa e de pressupor uma série de conhecimentos anteriores. Sem dúvida, trata-se de uma obra imprescindivel a todos aqueles que procuram manterse atualizados no debate da questâo urbana e regional, seja da perspectiva das políticas públicas, da gestăo ou ainda do planejamento. $\square$ 